\title{
Climate change impacts on meteorological, agricultural and hydrological droughts in China
}

\author{
Guoyong Leng a,b,*, Qiuhong Tang ${ }^{\mathrm{a}}$, Scott Rayburg ${ }^{\mathrm{c}}$ \\ a Key Laboratory of Water Cycle and Related Land Surface Processes, Institute of Geographic Sciences and Natural Resources Research, Chinese Academy of Sciences, Beijing 100101, China \\ b University of Chinese Academy of Sciences, Beijing 100049, China \\ c Water Resources Engineering Centre for Sustainable Infrastructure, Swinburne University of Technology, Hawthorn, VIC 3122, Australia
}

\section{A R T I C L E I N F O}

\section{Article history:}

Received 3 June 2014

Received in revised form 23 December 2014

Accepted 3 January 2015

Available online 15 January 2015

\section{Keywords:}

climate change impacts

droughts

China

\begin{abstract}
A B S T R A C T
Bias corrected daily climate projections from five global circulation models (GCMs) under the RCP8.5 emission scenarios were fed into a calibrated Variable Infiltration Capacity (VIC) hydrologic model to project future hydrological changes in China. The standardized precipitation index (SPI), standardized runoff index (SRI) and standardized soil moisture index (SSWI) were used to assess the climate change impact on droughts from meteorological, agricultural, and hydrologic perspectives. Changes in drought severity, duration, and frequency suggest that meteorological, hydrological and agricultural droughts will become more severe, prolonged, and frequent for 2020-2049 relative to 1971-2000, except for parts of northern and northeastern China. The frequency of long-term agricultural droughts (with duration larger than 4 months) will increase more than that of short-term droughts (with duration less than 4 months), while the opposite is projected for meteorological and hydrological droughts. In extreme cases, the most prolonged agricultural droughts increased from 6 to 26 months whereas the most prolonged meteorological and hydrological droughts changed little. The most severe hydrological drought intensity was about 3 times the baseline in general whereas the most severe meteorological and agricultural drought intensities were about 2 times and 1.5 times the baseline respectively. For the prescribed local temperature increments up to $3{ }^{\circ} \mathrm{C}$, increase of agricultural drought occurrence is predicted whereas decreases or little changes of meteorological and hydrological drought occurrences are projected for most temperature increments. The largest increase of meteorological and hydrological drought durations and intensities occurred when temperature increased by $1{ }^{\circ} \mathrm{C}$ whereas agricultural drought duration and intensity tend to increase consistently with temperature increments. Our results emphasize that specific measures should be taken by specific sectors in order to better mitigate future climate change associated with specific warming amounts. It is, however, important to keep in mind that our results may depend on the emission scenario, GCMs, impact model, time periods and drought indicators selected for analysis.
\end{abstract}

(c) 2015 Elsevier B.V. All rights reserved.

\section{Introduction}

Drought is a natural phenomenon mainly caused by below-normal precipitation over an extended period (Wilhite et al., 2000; Tallaksen et al., 2004; Mishra and Singh, 2010; Dai, 2012; Van Loon and Van Lanen, 2012). Droughts are complex events best characterized by a series of properties including their frequency, duration and intensity (Keyantash and Dracup, 2002; Mishra and Singh, 2010). Droughts can also take a variety of different forms depending on which part of the hydrological cycle they impact most strongly on. For example, a lack of precipitation over a prolonged period of time (several weeks to several years) manifests as a meteorological drought. Such droughts invariably propagate through the hydrologic cycle, however. Extended

\footnotetext{
* Corresponding author at: Guoyong Leng, Institute of Geographic Sciences and Natural Resources Research, Chinese Academy of Sciences, Beijing 100101, China

E-mail address: lenggy.11b@igsnrr.ac.cn (G. Leng).
}

meteorological droughts tend to cause hydrological droughts, or droughts characterized by a reduction in stream flow that occurs from both the loss of stream flow and a reduced occurrence of groundwater top-up events. A further consequence of extended meteorological droughts is the occurrence of agricultural droughts. These occur when the soil moisture is reduced over time from an ongoing lack of rainfall (Wilhite and Glantz, 1985; Hisdal et al., 2001; Keyantash and Dracup, 2002; Sheffield and Wood, 2008; Hayes et al., 2007). All types of droughts can be detrimental to both natural and anthropogenic systems. For example, below-normal water availability in rivers, lakes and reservoirs can cause water scarcity and often occurs in association with increasing water demand. This along with reduced water available for irrigation and in the soil column on account of the drought can threaten food production while also damaging aquatic ecosystems as ever greater proportions of the remaining water available are extracted for human uses (Döll et al., 2009; Wisser et al., 2010). The significance of droughts cannot be understated with droughts ranking first among all 
natural hazards when measured in terms of the number of people affected and the economic losses associated with their occurrence (Wilhite, 2000).

China is a frequently drought-affected country in East Asia since the monthly, annual and inter-annual variations in precipitation and temperature are significant there (Ma and Fu, 2003; Dai et al., 2004; Zou et al., 2005). As reported by the Ministry of Water Resources of China (MWRC, 2011), extreme droughts occurred every 2 years on average for the period 1990-2007. The average grain loss associated with these droughts is nearly 39.2 billion kg annually, with the average economic loss accounting for $1.47 \%$ of the country's gross domestic product. During the past decade, droughts were common in all parts of China from south to north, and resulted in serious social, economic and environmental consequences (Wang et al., 2012). For example, the recent winter drought which hit the northeast of China in 20082009 left more than 10 million people struggling with water shortages and led to total economic losses of up to $\$ 2.3$ billion (Wang et al., 2011a, 2011b). Other examples include, the record-breaking severe and sustained droughts occurred in 2006 (Li et al., 2009) and 20092010 (Yang et al., 2012) in Southwest China that caused devastating and far-reaching impacts to agriculture, society, the economy, and many ecosystems (Zhang et al., 2012a,b).

The devastating impacts of droughts in China have spurred many scientific studies, with focus on particular drought components, such as precipitation, runoff/stream flow, or soil moisture. For example, using the precipitation-based China-Z index, Wang and Zhai (2003) showed an expanding area of drought affected lands in agricultural regions of northern China during the past 50 years. Ma and Fu (2003) also revealed a drying trend in major parts of North China during 1951-1998 using a surface humidity index. These patterns are not confined to northern China only however. Indeed, Wu et al. (2011) reconstructed China's daily soil moisture values from 1951 to 2009 and showed that up to $30 \%$ of the total area of China is prone to drought and Wang et al. (2011a, 2011b) showed that over the past 60 years severe droughts in China grew increasingly common, suggesting an increasing risk on sustainable agricultural productivity across the whole nation. Zou et al. (2005) used the Palmer Drought Severity Index (PDSI) to investigate the variations in droughts over China, and Zhai et al. (2010) used both PDSI and standardized precipitation index (SPI) to identify tendencies in dry/wet conditions during recent decades over ten large regions in China. Both found an increasing trend of droughts across major regions of China in the past decades. Despite this intense research focus on droughts in China, a missing component of this research has been a consideration of the different types of droughts (namely meteorological, hydrological and agricultural). As each manifests differently and has unique implications for natural and anthropogenic systems, this is a significant omission. To fully understand and manage drought in China it is imperative to develop a more complete picture of how these different types of droughts operate and how their frequency, duration and intensity have been changing in the recent past and may continue to change in the future, particularly as a result of climate change.

It has observed that there has been an increase in drought risk globally since the late 1970s, due to enhanced evaporation (on account of increasing global temperatures) without any increase in precipitation in most locations (Sheffield and Wood, 2008; Zou et al., 2005; Dai, 2012; Trenberth et al., 2014). Within the context of future global warming as a result of an increase in greenhouse gases (IPCC, 2013), it is of great significance to assess the climate change impacts on droughts at the regional scale and, more importantly, to determine which types of droughts will be most affected (i.e., meteorological, hydrological and/ or agricultural). Several studies have quantified the potential changes of hydrology and water resources in basins in North China (e.g., Xu et al., 2009c; Li et al., 2010; Yang et al., 2012), South China (e.g., Jiang et al., 2007; Qiu, 2010; Wang et al., 2014) and the whole country (e.g., Guo et al., 2002; Wang et al., 2012; Leng et al., in press). However, very few studies have examined the impacts of climate change on droughts at the river basin scale (e.g. Duan and Mei, 2014). There has also been little effort to explicitly examine the potential impacts of future climate change on droughts across the whole country, and especially, the sensitivities of various drought type (e.g. the meteorological, agricultural and hydrological droughts) responses to different climate warming amounts. Understanding whether certain types of droughts are more sensitive to projected climate change than others could potentially identify which sector(s) is most sensitive to changing drought frequencies, durations and intensities enabling more effective drought management plans to be developed. Indeed, results from such a comprehensive study over the whole country could be used not only to inform on potential impacts for specific sectors but also can be used to coordinate adaptation/mitigation strategies among different sectors/regions by the central government. Thus, the objective of this research is to assess the potential impacts of future climate change on drought characteristics in different domains of the hydrological cycle in China. To address this, we used bias-corrected daily outputs from state of the art climate models as inputs for a calibrated hydrologic model configured over the whole of continental China. Based on future water resource scenarios, drought characteristics were then assessed using various drought indices and the implications of the changes in drought characteristics are discussed.

\section{Data and methodology}

\subsection{Bias-corrected climate projections}

The fast-track of the Inter-Sectoral Impact Model Inter-comparison Project (ISI-MIP) aims to quantify the uncertainty in climate scenarios, climate models, and impact models that project climate change impacts on water, biomes and agriculture (Warszawski et al., 2013). Within the framework of ISI-MIP, climate projections from 5 global circulation models (HadGEM2-ES, GFDL-ESM2M, IPSL-CM5A-LR, MIROC-ESMCHEM and NorESM1-M, see Table 1 for details) driven by multiple Representative Concentration Pathway (RCP) scenarios were obtained at a $0.5^{\circ} \times 0.5^{\circ}$ spatial resolution and a daily time step from 1950 to 2099 (Hagemann et al., 2013). These datasets were bias-corrected to the WATCH Forcing data (WFD) (Weedon et al., 2011) enabling us to adequately represent the effects of changes in climate variability in addition to changes in the climate mean (Hempel et al., 2013), which is important for the investigation of extreme hydrological events. The bias correction method is based on a distribution-based bias correction algorithm which was adopted in the WaterMIP/WATCH (Piani et al., 2010; Hagemann et al., 2011). Specifically, a multiplicative algorithm that preserves the relative changes (e.g. precipitation) and an additive approach that preserves the absolute changes (e.g. temperature) were first applied to the GCM data to match the WFD climatology. The residual or normalized data are then applied to a parametric quantile mapping approach for adjusting the daily variability of GCM data to match that of the WFD. Subsequently, the derived monthly correction

Table 1

Descriptions of the 5 global circulation models used in this study.

\begin{tabular}{|c|c|c|}
\hline Model name & Institute acronyms & Institute full name \\
\hline GFDL-ESM2M & NOAA GFDL & $\begin{array}{l}\text { NOAA Geophysical Fluid Dynamics } \\
\text { Laboratory }\end{array}$ \\
\hline HadGEM2-ES & $\begin{array}{l}\text { MOHC (additional } \\
\text { realizations by } \\
\text { INPE) }\end{array}$ & $\begin{array}{l}\text { Met Office Hadley Centre and Instituto } \\
\text { Nacional de Pesquisas Espaciais }\end{array}$ \\
\hline IPSL-CM5A-LR & IPSL & Institut Pierre-Simon Laplace \\
\hline MIROC-ESM-CHEM & MIROC & $\begin{array}{l}\text { Japan Agency for Marine-Earth Science } \\
\text { and Technology, Atmosphere and Ocean } \\
\text { Research Institute (The University of } \\
\text { Tokyo), and National Institute for } \\
\text { Environmental Studies }\end{array}$ \\
\hline NorESM1-M & NCC & Norwegian Climate Centre \\
\hline
\end{tabular}


factors were interpolated towards daily ones and applied to the future climate projections. Details for the bias-correction method can be found in Hempel et al. (2013). In this study, we used the bias-corrected climate data from all $5 \mathrm{GCMs}$ to provide a robust estimation of future changes in drought hazards in China. The RCP8.5 scenario was selected to highlight the largest climate change impacts since the largest possible temperature change is covered under this greenhouse gas emission scenario (Moss et al., 2010; Rogelj et al., 2012). Similar to other studies using the RCP8.5 scenario (e.g. Piontek et al., 2014; Elliott et al., 2014; Schewe et al., 2014), the results obtained in this study should represent the potential upper bounds of climate change impacts on droughts.

\subsection{Off-line land surface model simulation}

In this study, the physically based, semi-distributed macroscale Variable Infiltration Capacity (VIC) model (Liang et al., 1994, 1996) was used to project future water resource scenarios for China. The VIC model has been widely applied for analyzing drought events at regional and global scales (e.g. Andreadis et al., 2005; Sheffield and Wood, 2008; Shukla and Wood, 2008) and it allows for the simulation of both the water and energy budgets for each grid cell to be simulated. In the VIC model, the sub-grid variability of vegetation, soil and terrain characteristics was represented through sub-grid area-specific parameter classifications. Soil texture and bulk densities were derived by combining the 5-min digital soil map of the world by the Food and Agricultural Organization - United Nations Educational, Scientific, and Cultural Organization (FAO, 1998) with the World Inventory of Soil Emission Potentials database (Batjes, 1995). The remaining soil characteristics (e.g. porosity, saturated hydraulic conductivity and unsaturated hydraulic conductivity) were based on the work of Cosby et al. (1984).Vegetation type data were taken from the Advanced Very High Resolution Radiometer-based global land classification of Hansen et al. (2000). The six hydrologic parameters required as input into the VIC model, i.e. the infiltration parameter $b$, the second and third soil layer depths (d2, d3) and the three parameters of the baseflow scheme (Dm, Ds, Ws), were calibrated based on observed daily stream flow for the ten river basins over China. Details for the model calibration and validation process can be found in Zhang et al. (2014). By using the bias-corrected climate data as inputs, time series of daily hydrologic terms from the VIC model were generated for the period 1950-2099. We excluded the first 20 years of results to accommodate model spin-up thereby eliminating the impact of initial conditions and thus started our analysis from 1971 to 2099.

\subsection{Drought analysis method}

In this study, we used the standardized precipitation index (SPI) (McKee et al., 1993), the standardized soil moisture index (SSWI) (Wang et al., 2011a, 2011b) and the standardized runoff index (SRI) (Shukla and Wood, 2008) to characterize the meteorological, agricultural, and hydrological droughts respectively. The SPI is computed on the basis of probability distributions of precipitation for specified monthly time scales. In this study, the 1-month SPI was obtained by fitting a gamma distribution to each month separately. The gamma distribution was adopted since the distribution of monthly precipitation is typically similar to a gamma distribution (Wilks and Eggleston, 1992). The detailed formulation of the SPI calculation can be found in Loukas and Vasiliades (2004). The calculation procedure adopted in this study is given by McKee et al. (1993) and Mishra and Desai (2005). The range of the SPI is about the same for every location over the study period (e.g. SPI is within $<-2,+2>$ with about $95 \%$ probability), since the SPI is designed to express drought conditions with respect to normal conditions at a given site for a given period. Hence, for drought comparisons between different grid cells or between different time periods, the standardized index may not be good for applications. This is a limitation as such considerations are essential in assessing the potential impacts of climate change. Therefore, for a given grid cell, we first constructed the distributions for the historical precipitation and then applied the derived parameters in fitting the future projections (Dubrovsky et al., 2009; Burke, 2011; Wang et al., 2012). To accomplish this we assumed that the parameters of the gamma distribution would be unchanged in the future and so the values adopted for the historical period could be extended to the future predictions. Several studies assessing climate change impacts using standardized drought indices have adopted the same technique (e.g. Loukas et al., 2007; Loukas et al., 2008; Dubrovsky et al., 2009; Wang et al., 2012). The calculation procedure for SRI and SSWI is similar to the SPI but by fitting a log probability
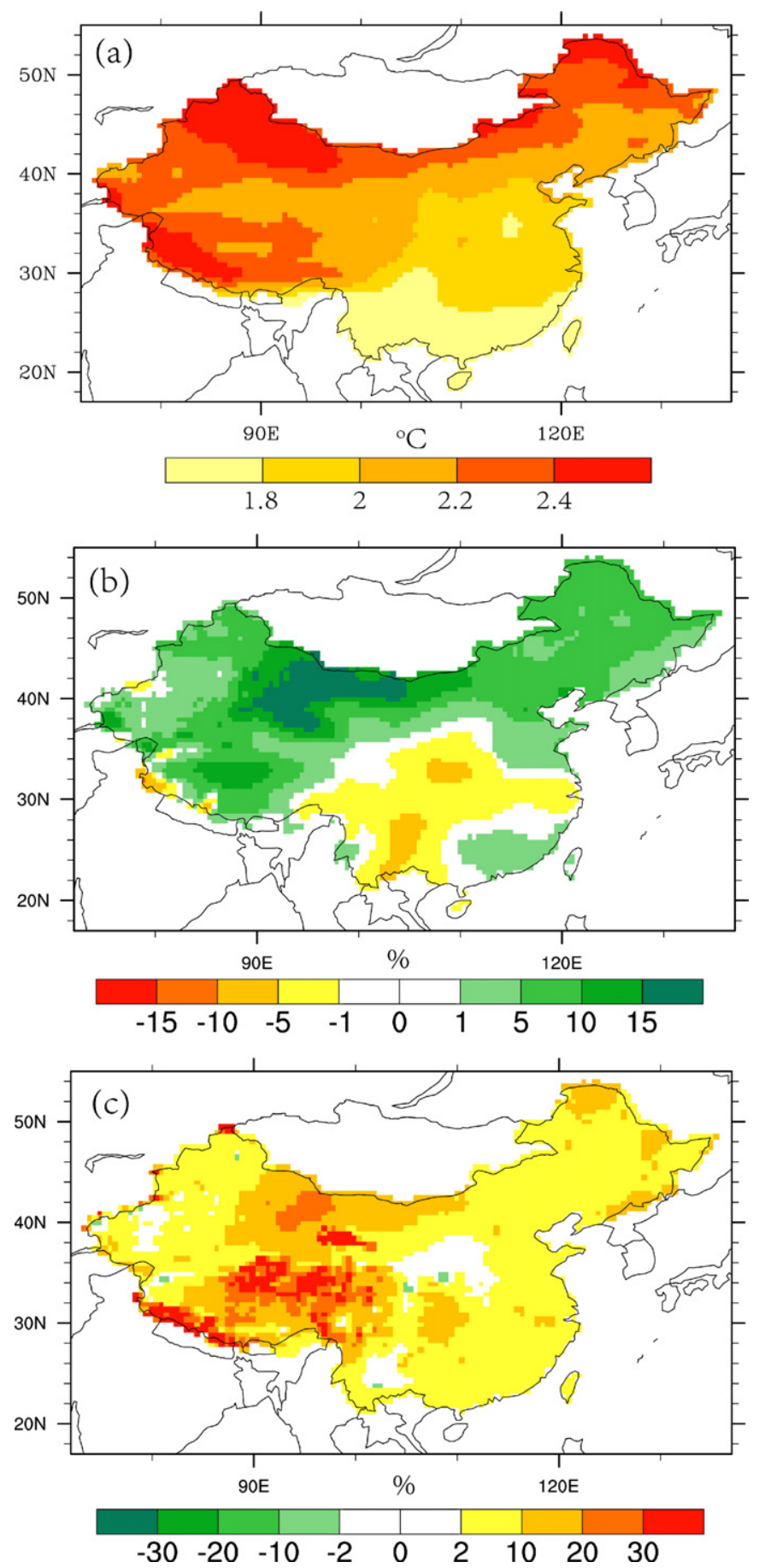

Fig. 1. Changes in (a) temperature $\left({ }^{\circ} \mathrm{C}\right)$, (b) precipitation (\%) and (c) actual evapotranspiration (\%) for the future period 2020-2049 relative to the current period 1971-2000. 
density function to the given frequency distribution of runoff and soil moisture series respectively.

Time series of the drought indices were calculated over land grid cells in China for each model. A drought event was considered as the period of time when drought index (i.e. SPI, SSWI and SRI) values are below -1.0 , indicating that the deviation from average conditions exceeds one standard deviation. In order to examine drought characteristics, three different parameters were used: (1) frequency - the number of droughts over a defined period; (2) duration - the length of each drought event; and (3) intensity - the average SPI value for a drought event. The percentage change in drought index values for the near future period 2020-2049 with respect to the current period 1971-2000 was used to investigate the changes in drought characteristics. The near future period 2020-2049 was selected because the results for this period would be most useful for decision makers.

\section{Results}

The multi-model ensembles (MME) mean results predict a warmer climate for the whole country with a temperature increase of $1-4{ }^{\circ} \mathrm{C}$ (Fig. 1a). The largest increase is expected in northwestern, southwestern and northeastern China, with the smallest increase in south China. Unlike for temperature where warming will occur across the whole of China to some degree or another, the response of rainfall to climate change is much more variable and regionally specific (Fig. 1b). According to model projections, western and northern China, and the south coast will experience an increase in future precipitation by $5 \%-15 \%$. In major areas of central and parts of southwest China, the model results show a decrease of up to $10 \%$. The spatial pattern of changes in actual evapotranspiration (ET) is similar to that of precipitation in that it is highly variable but like temperature is generally predicted to increase across the whole of China. In general, average ET will increase because of increased temperatures, especially in southwest, northwest and parts of northeastern China (Fig. 1c).

\subsection{Spatial pattern of changes in mean drought characteristics}

Fig. 2 shows the multi-model ensemble changes in drought frequency, mean duration and mean intensity for 2020-2049 against 19712000. The occurrence of meteorological drought (i.e. SPI) consistently decreases in northeast China, parts of northwest China and major regions of the Yellow River Basin. However, the remainder and largest parts of the country will see an increase in exposure to meteorological drought events. Both the mean duration and intensity of meteorological droughts are expected to increase across the whole country especially for arid and sub-arid regions over the western part of China. Previous studies show that climate warming will lead to more intense heavy rains but longer dry spells in China (e.g., Gao et al., 2002; Xu et al., 2009b, 2012, 2013), which means that more water could run off reducing the amount available to infiltrate and replenish the soil moisture (Trenberth et al., 2014). Our results support this supposition showing increases in the frequency, duration and intensity of agricultural (or soil moisture) droughts in almost all areas (Fig. 2b, e, h), with the most severe increases found in the northwestern and southwestern arid regions of China, with agricultural drought frequency showing positive anomalies greater than $60 \%$ in those regions. Thus, many of the areas most susceptible to soil moisture drought as reported in the last decades (Wang et al., 2011a, 2011b) will experience the greatest
SPI
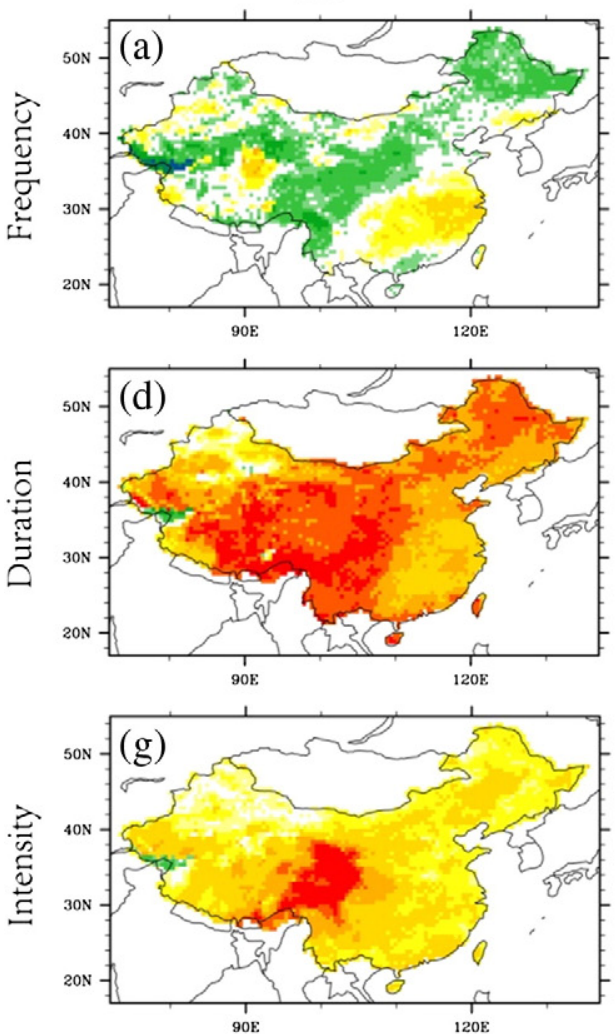

SSWI
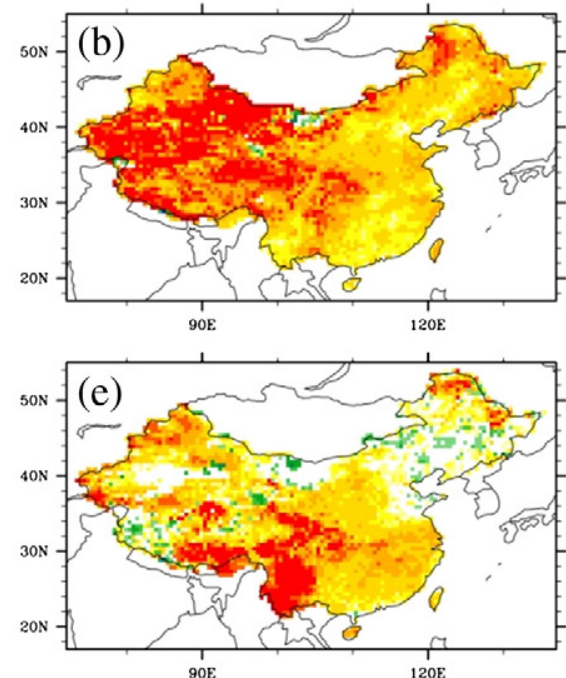

$90 \mathrm{E}$

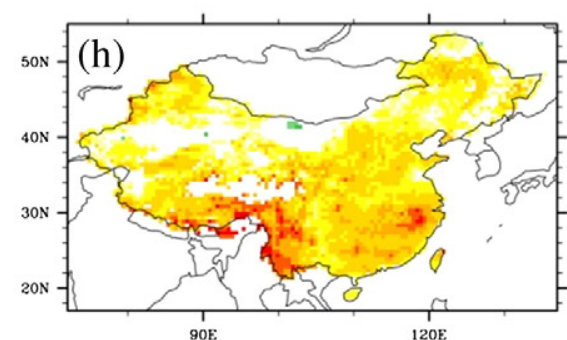

SRI


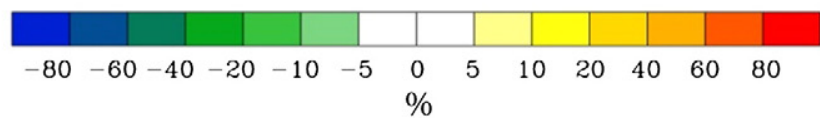

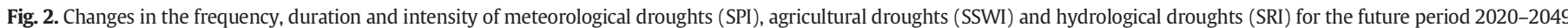
relative to the current period 1971-2000. 

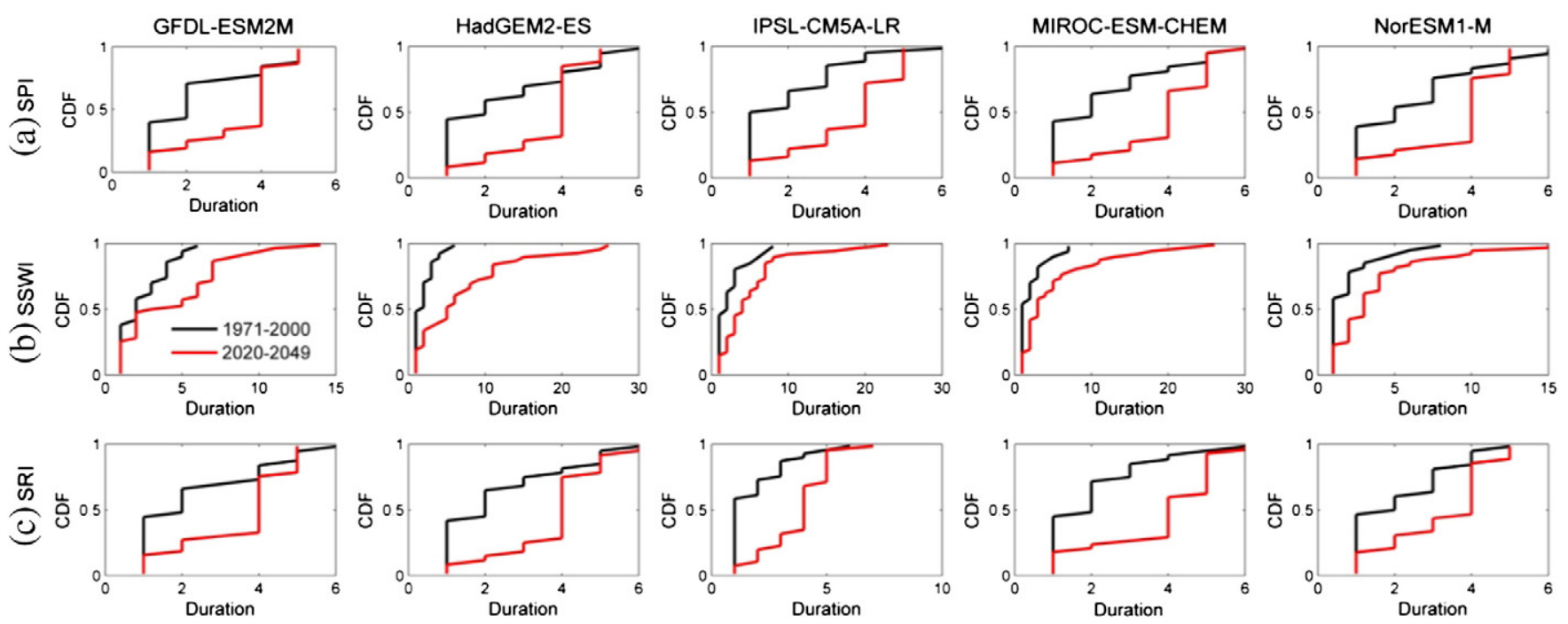

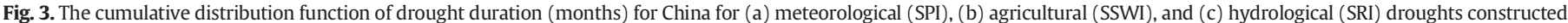
for the current and future periods. Drought events are identified when index values are less than -1 .

increase in agricultural drought frequency in the near future. The changes in hydrological droughts (i.e. SRI) frequency generally reflect changes in precipitation over China. For example, the frequency of hydrological droughts decreased significantly over major parts of north and northeast China in association with reductions in meteorological drought frequencies in those areas. However, for both drought duration and intensity, the links are less clear with northeast China predicted to experience reduced hydrological drought duration and intensity while the duration and intensity of meteorological droughts are predicted to increase in the same area. Regionally, the increase in hydrological drought duration is more pronounced in southwest China (large areas greater than $80 \%$ ) and less severe in the southeast China although the whole of southern China will experience increased hydrological drought durations and to a lesser extent and increase in hydrological drought intensity.

Fig. 3 shows the cumulative distribution frequency (CDF) curves for the duration of meteorological, agricultural, and hydrological drought events averaged over China for the current and future periods for each GCM. Large variations exist in the magnitude of changes in drought duration among the five GCMs. However, it was found that all five models projected a longer duration of meteorological, agricultural, and hydrological droughts throughout the CDF curves in the future relative to the current period. Moreover, the disproportional changes in drought duration along the CDF curves for all three types of droughts were found. For both hydrological and meteorological droughts, the increase in drought duration was projected to be more notable for the low frequency droughts than those high frequency droughts in the future. In contrast, the greater increase in agricultural drought duration is predicted to occur for the high frequency droughts compared to a relatively small increase in rare drought duration. However, all models predict that the duration of the most infrequent agricultural droughts will increase significantly in the future although they will still occur only rarely. These results suggest that the frequency of long-term (with duration larger than 4 months) meteorological and hydrological droughts is expected to increase less significantly than that of shortterm (with duration less than 4 months) droughts, while the reverse is true for agricultural droughts. In extreme cases, the most prolonged agricultural droughts increased from 6 to 26 months in length as projected by HadGEM2-ES and MIROC-ESM-CHEM, whereas the most prolonged meteorological and hydrological droughts changed little. These results suggest that precipitation is closely linked to stream hydrology and these respond to drought conditions very quickly and
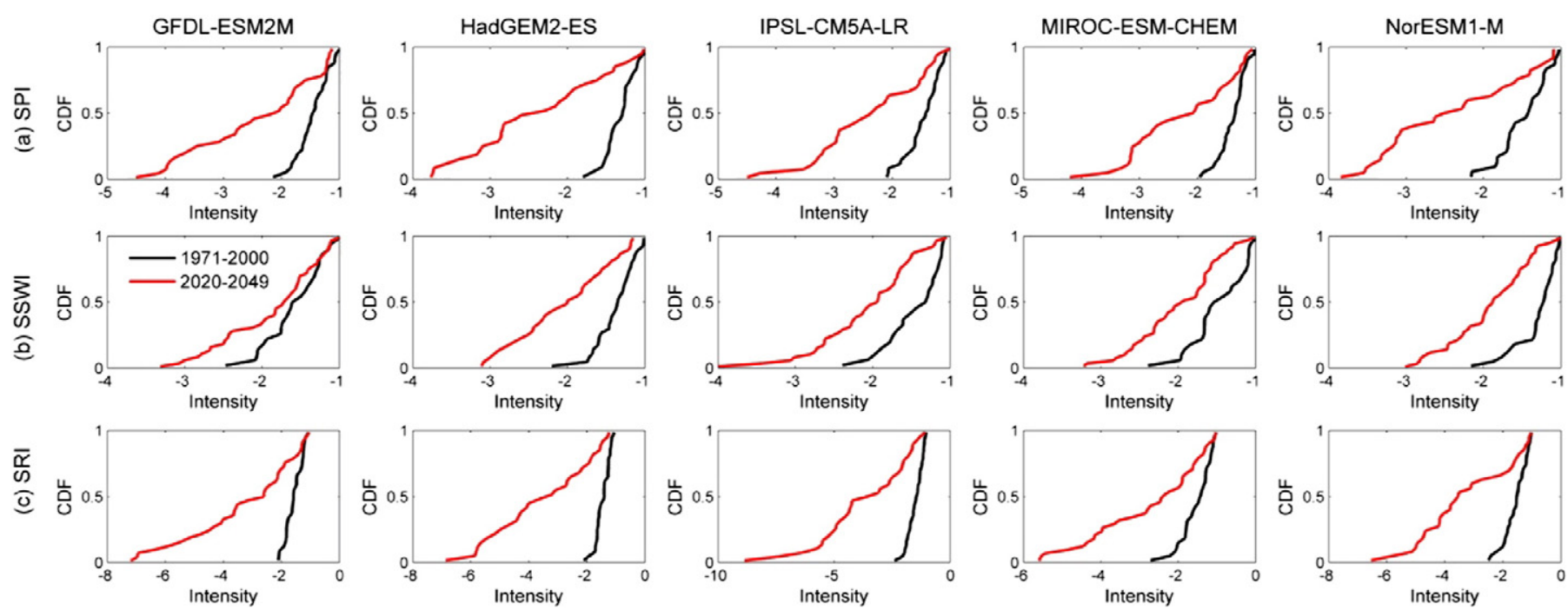

Fig. 4. Same as Fig. 3 but for drought intensity. 
SPI

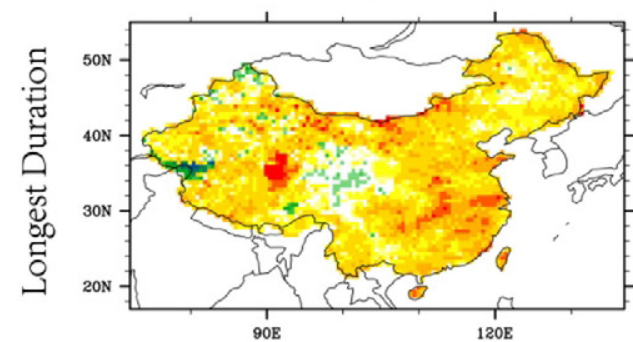

$90 \mathrm{E}$

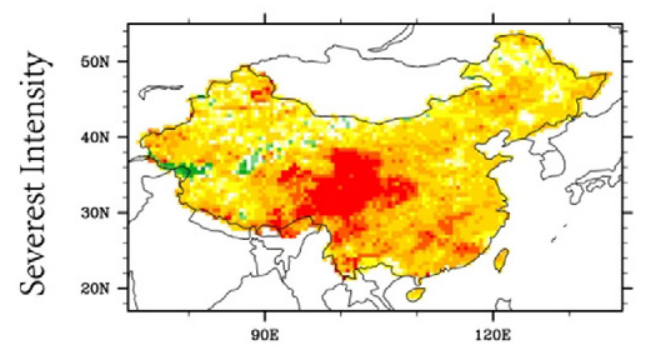

SSWI
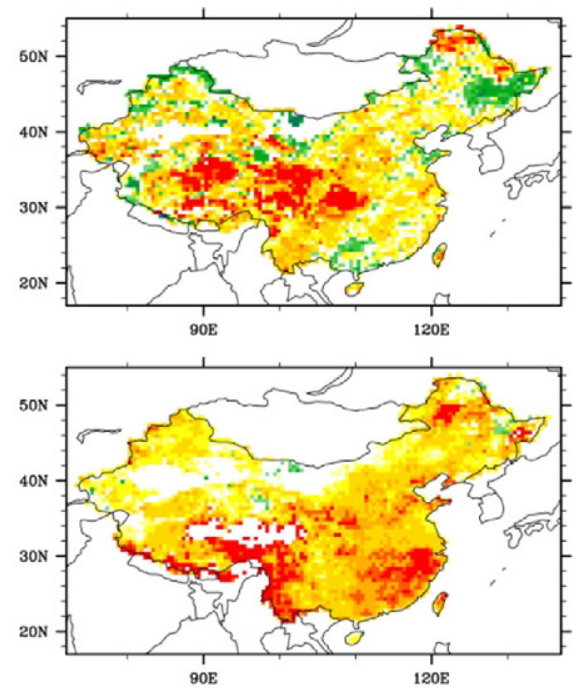

SRI
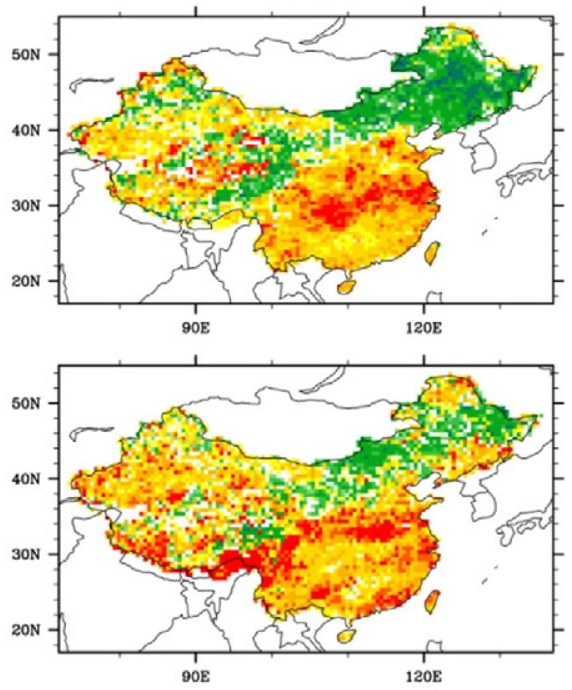

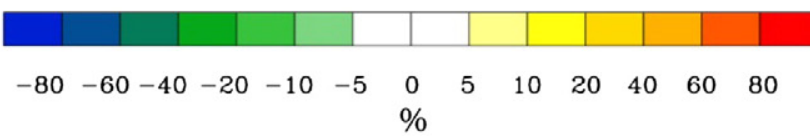


future period 2020-2049 relative to the current period 1971-2000.

recover from drought conditions very quickly, while the effect of reduced precipitation can generate a longer term deficit in soil moisture that persists well after precipitation rates return to normal.

Similar results were found for the drought intensity as shown in Fig. 4. For example, all models predicted an increase in drought intensity throughout the CDF curves in the near future. The most severe drought (i.e., the most negative drought intensity) is projected to increase significantly for meteorological, agricultural and hydrological droughts based on all of the five GCMs. However, the impact of future climate change is most pronounced for hydrological droughts with index values greater than -9 predicted for some GCMs (compared to values generally less than -5 for meteorological and agricultural droughts). This amounts to an increase in drought intensity for the most severe hydrological droughts about 3 times higher than the baseline whereas the most severe meteorological and agricultural drought intensities are only about 2 times and 1.5 times the baseline respectively.

\subsection{Spatial patterns of change in extreme droughts and their social impacts}

Extreme drought events, those with extended durations and/or of high intensity, are generally of most concern for drought management. As described above using CDF curves, extreme drought conditions are projected to increase for all types of droughts across the majority of China. Fig. 5 illustrates the spatial distribution of changes in droughts with the longest duration and the most severe drought intensities of any duration between 1971-2000 and 2020-2049. The spatial pattern of change in extreme droughts was consistent with the changes already described in mean drought conditions (Fig. 2). For example, the longest duration and severest droughts (of all types) are predicted to increase most over southwest and southeast China while the extreme hydrological droughts are projected to decrease in major parts of northeastern China and the upper reaches of the Yellow River basin a pattern similar to that previously shown for mean drought conditions in Fig. 2. Moreover, the percentage increase in the longest duration of meteorological and hydrological drought is lower than that in mean duration in most parts of the country while the opposite is true for intensity (i.e., percentage increase in intensity for the severest droughts exceeds those for the mean droughts). These results are consistent with the findings from the disproportional changes along the CDF curves as shown in Figs. 3 and 4.

By the 2030s, the longest duration droughts will increase by more than $10 \%$ for $79.8 \%, 60.8 \%$ and $56.2 \%$ of the total land area of China for meteorological, agricultural and hydrological droughts respectively (Table 2). This also amounts to $93.7 \%, 61.9 \%$ and $82.6 \%$ of the country's population of 1.3 billion suffering from these increased drought durations in meteorological, agricultural and hydrological droughts respectively. Hence, in terms of both area and population affected, the increase in drought duration is most pronounced for meteorological droughts although the significant increase in duration of the longest droughts will affect at least $55 \%$ of the land area and $60 \%$ of the population regardless of drought type. Similar results were also found for the percentage of population and land area affected by the most severe droughts (Table 3 ). That is, $94.7 \%, 96.2 \%$ and $85.8 \%$ of the population will be exposed to an increase of more than $10 \%$ in the intensity of the most severe droughts for meteorological, agricultural and hydrological droughts respectively, while the corresponding numbers for land area affected are $86.8 \%, 81.8 \%$ and $68.6 \%$. Hence, the vast majority of the land area and population of China are set to be subjected to significantly longer and more severe droughts of all types in the future on account of climate change.

Furthermore, an increase of more than $70 \%$ in the longest duration of meteorological, agricultural and hydrological droughts will affect about 32.4, 81.6 and 205.1 million people respectively (Table 2) while 70.7,

Table 2

Population (in \% of total population of China) and areas (in \% of total land area of China) affected by changes in longest duration of meteorological (SPI), agricultural (SSWI) and hydrological (SRI) droughts between 1971-2000 and 2020-2049.

\begin{tabular}{|c|c|c|c|c|c|c|}
\hline \multirow{2}{*}{$\begin{array}{l}\text { Longest duration } \\
\text { changes (\%) }\end{array}$} & \multicolumn{2}{|l|}{ SPI } & \multicolumn{2}{|l|}{ SSWI } & \multicolumn{2}{|l|}{ SRI } \\
\hline & $\begin{array}{l}\% \text { of } \\
\text { pop. }\end{array}$ & $\begin{array}{l}\% \text { of land } \\
\text { area }\end{array}$ & $\begin{array}{l}\% \text { of } \\
\text { pop. }\end{array}$ & $\begin{array}{l}\% \text { of land } \\
\text { area }\end{array}$ & $\begin{array}{l}\% \text { of } \\
\text { pop. }\end{array}$ & $\begin{array}{l}\text { \% of land } \\
\text { area }\end{array}$ \\
\hline$>70$ & 2.49 & 2.37 & 6.26 & 10.03 & 15.72 & 7.30 \\
\hline $30-70$ & 51.71 & 35.93 & 18.80 & 21.71 & 49.89 & 29.09 \\
\hline $10-30$ & 39.57 & 41.58 & 36.93 & 29.11 & 17.06 & 19.84 \\
\hline-10 to 10 & 6.11 & 18.07 & 30.85 & 28.50 & 5.96 & 15.22 \\
\hline$<-10$ & 0.12 & 2.05 & 7.16 & 10.64 & 11.38 & 28.55 \\
\hline
\end{tabular}


Table 3

Population (in \% of total population of China) and areas (in \% of total land area of China) affected by changes in drought intensity for meteorological (SPI), agricultural (SSWI) and hydrological (SRI) droughts between 1971-2000 and 2020-2049.

\begin{tabular}{|c|c|c|c|c|c|c|}
\hline \multirow{2}{*}{$\begin{array}{l}\text { Severest drought } \\
\text { changes (\%) }\end{array}$} & \multicolumn{2}{|l|}{ SPI } & \multicolumn{2}{|l|}{ SSWI } & \multicolumn{2}{|l|}{ SRI } \\
\hline & $\begin{array}{l}\% \text { of } \\
\text { pop. }\end{array}$ & $\begin{array}{l}\% \text { of land } \\
\text { area }\end{array}$ & $\begin{array}{l}\% \text { of } \\
\text { pop. }\end{array}$ & $\begin{array}{l}\% \text { of land } \\
\text { area }\end{array}$ & $\begin{array}{l}\% \text { of } \\
\text { pop. }\end{array}$ & $\begin{array}{l}\% \text { of land } \\
\text { area }\end{array}$ \\
\hline$>70$ & 5.42 & 11.05 & 11.21 & 12.82 & 20.93 & 13.90 \\
\hline $30-70$ & 56.70 & 41.21 & 52.25 & 34.56 & 44.58 & 32.59 \\
\hline $10-30$ & 32.24 & 34.63 & 32.74 & 34.43 & 20.34 & 22.10 \\
\hline-10 to 10 & 5.60 & 11.86 & 3.76 & 17.78 & 8.59 & 16.38 \\
\hline$<-10$ & 0.04 & 1.25 & 0.04 & 0.41 & 5.57 & 15.03 \\
\hline
\end{tabular}

146.2 and 272.9 million people will suffer from an increase of more than $70 \%$ in the severity of the most intense meteorological, agricultural and hydrological droughts respectively (Table 3 ). These data indicate that extreme drought conditions are likely to be a considerable challenge in coming years with large portions of the population subjected to such conditions.

\subsection{Sensitivity of drought projections to prescribed climate warming}

Some of the model differences within each of the RCP8.5 periods could exist due to differences in global climate sensitivity and greater model agreement at common levels of climate warming could be expected than at common levels of forcing (Tang and Lettenmaier, 2012; Diffenbaugh et al., 2013). Therefore, projections of future droughts to different levels of prescribed temperature increments up to $3{ }^{\circ} \mathrm{C}$ were assessed (Fig. $6-8$ ). To reflect regional variability, the degree of warming was calculated for the specific region studied (see Table 4). Adopting this approach, it was found that agricultural drought occurrence (frequency) is predicted to increase for all temperature increments for the whole country as well as the ten river basins (Fig. 6). That is, as temperature continues to increase so too will the incidence (frequency) of agricultural droughts. Hence this drought type is very sensitive to continued rises in temperature. However, the same is not true for either meteorological or hydrological droughts. For these, only small changes or in many cases no changes in the occurrence (frequency) of droughts are evident with continued increases in temperature. Hence, the frequency of occurrence of these two drought types seems to be insensitive to continued rises in temperature (Fig. 6). In terms of both drought duration and intensity, however, the story is more complex. Here each region and river basin has its own unique response to continued rises in temperature. In some cases the duration and intensity of all three drought types increase with increasing temperature, in other parts of China they may stay the same or even decrease (Figs. 7 and 8). Moreover, the sensitivity to continued climate warming for the three drought types is also very region specific. However, when averaged over the whole of China, agricultural droughts were most sensitive to continued warming in terms of their drought duration (compared to the other two drought types) while hydrological droughts were found to be most sensitive to continued climate warming in terms of their intensity (compared to the other two drought types).

A significant finding of this regional analysis is that there is a non-linear and non-directional response of hydro-meteorological droughts to temperature increments up to $3{ }^{\circ} \mathrm{C}$. For example, model results show a negative quasi-linear trend between percentage increase in the duration of meteorological and hydrologic droughts with temperature increments larger than $1{ }^{\circ} \mathrm{C}$ for the country as well as most of the river basins (Fig. 7). Indeed, the largest percentage increase of drought duration occurred when temperature increased by $1{ }^{\circ} \mathrm{C}$ compared to other temperature increments. This indicates that the duration of
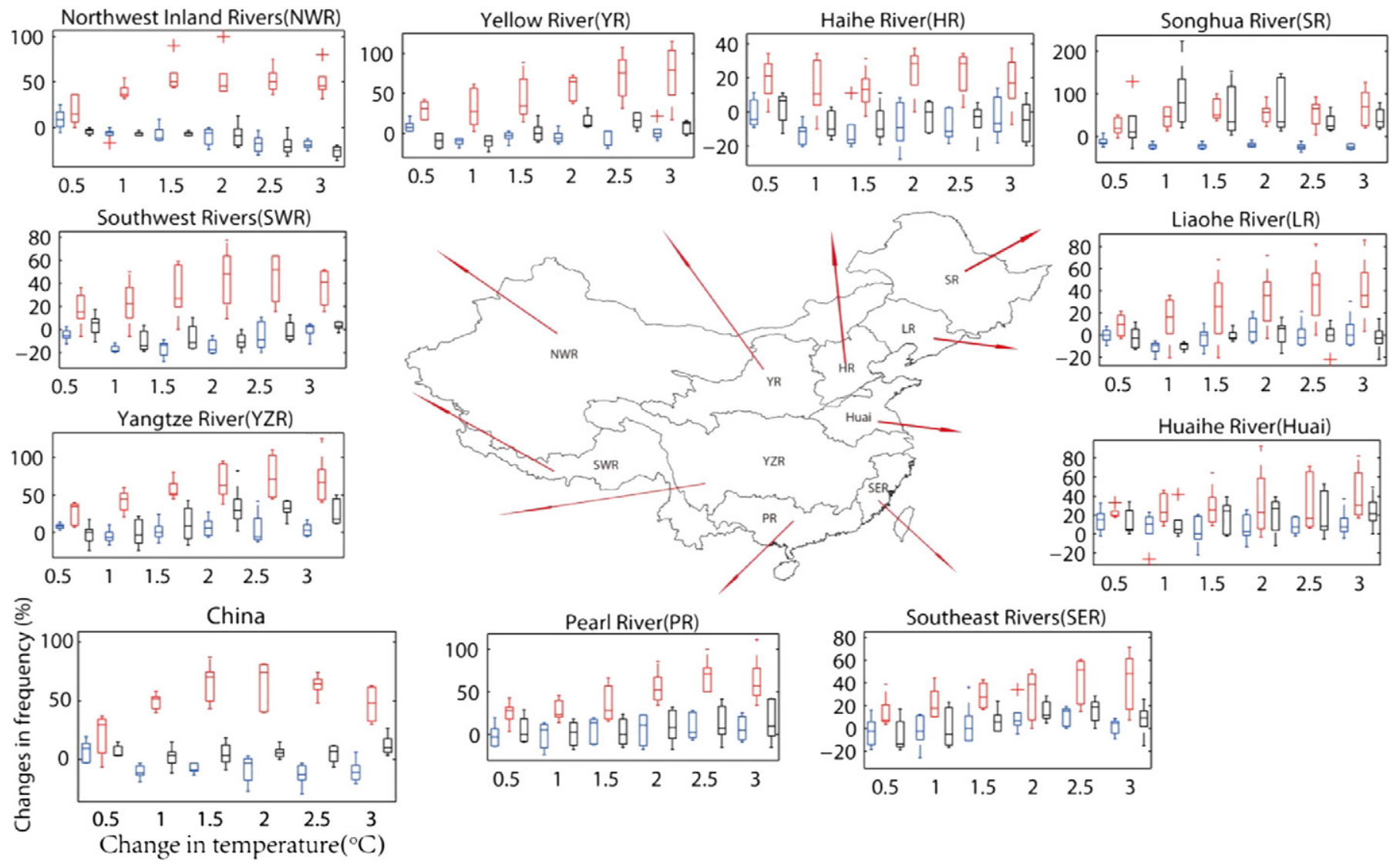

SPI

SSWI

SRI

Fig. 6. Sensitivity of drought frequency to prescribed local temperature increments up to $3{ }^{\circ} \mathrm{C}$. 
droughts may actually be reduced as temperatures begin to exceed a 1 ${ }^{\circ} \mathrm{C}$ increase. Similar results were found when looking at the response of drought intensity to the prescribed temperature increments (Fig. 8). Our results suggest that higher warming scenarios might not necessarily result in larger or more significant impacts on droughts. The causal mechanisms for this non-linearity remain unknown but the results suggest that no "one size fits all" drought management strategy can be used to account for all possible future warming scenarios. Moreover, each drought type did respond differently to increasing temperatures so this adds an extra level of complexity to drought management and climate change mitigation. For example, although a continued increase in temperature beyond $1{ }^{\circ} \mathrm{C}$ seems to be beneficial in terms of reducing the effects of meteorological and hydrological droughts, such temperature increases resulted in much more severe agricultural droughts. Developing an effective drought mitigation strategy in light of these variations will be a significant challenge in the future.

\section{Uncertainty and limitations of this study}

In climate change impact assessments, uncertainties may arise from various sources such as emission scenarios (Maurer, 2007), GCM structure (Kirono et al., 2011), downscaling/bias-correction methods (Chen et al., 2011), and impact models (Schewe et al., 2014). The climate projection datasets used in this study were obtained from the ISI-MIP, which aims at providing timely climate change impact assessments for IPCC AR5 based on CMIP5. Unfortunately, only 5 GCMs were statistically downscaled and bias-corrected in the fast-track of ISI-MIP when this study was initiated, which makes it impossible to fully characterize the potential uncertainty ranges by GCMs. After bias-correction, however, the GCMs used in this study can reproduce the observed climate very well (Hempel et al., 2013). In addition, several studies have demonstrated the value of using the same climate projections by the 5 GCMs in hydrological climate change impact assessments at the global and regional scales (e.g., Piontek et al., 2014; Elliott et al., 2014; Schewe et al., 2014; Haddeland et al., 2014; Prudhomme et al., 2014; Dankers et al., 2014).

Another potential issue source of uncertainty in this study is the choice of reference dataset. Here, the climate projections were comprehensively validated against the WATCH forcing data at $0.5^{\circ}$ within the ISI-MIP. Hence, the adjusted climate projections would be potentially different if based on different reference datasets (e.g. Xu et al., 2009a; Wu and Gao, 2013), as used in evaluating the GCM/RCM performance (e.g. Xu and Xu, 2012a, 2012b; Jiang and Tian, 2013). However, investigating the relative utility of one or another reference dataset is not the purpose of this study nor is it our aim to validate the GCMs again. Rather, our main goal is to demonstrate the similar/different responses of three drought types to climate projections, which have been comprehensively validated by other researchers.

Results should also depend on the specific time periods, which are associated with varying cumulative radiative forcing and climate warming magnitudes. In hydrological climate change impact studies, various time periods have been adopted as the reference period (i.e. present time period) such as the 1980-2010 (e.g. Piontek et al., 2014), 1976-2005 (e.g. Prudhomme et al., 2014), 1985-2005 (e.g. Hinkel et al., 2014), 1996-2005 (e.g. Orlowsky et al., 2014), as well as 19712000 (e.g. Portmann et al., 2013; Dankers et al., 2014; Haddeland et al., 2014) which was used in this study. The near term period of 2020-2049 was selected in this study to better inform policy-makings and mitigation/adaptation strategies for this specific immediate future. And our analyses based on 2020-2049 relative to 1971-2000 are consistent with that using other similar periods (e.g. 2016-2035 relative to 1986-2005) (results not shown) and may not affect our conclusions in this study. Although it is possible that natural variability may be large enough to overwhelm the GHG signals over this near-future


Change in temperature $\left({ }^{\circ} \mathrm{C}\right)$

SPI 
term period, determining when the GHG signals dominate the natural variability is a topic not within the scope of this study. The use of this period for near term prediction has also been adopted in many other studies (e.g. Hayhoe et al., 2004; Vicuna et al., 2007; Mariotti et al., 2008; Biasutti et al., 2012; Aich et al., 2014; Lopez et al., 2014).

There are many approaches to calculate droughts e.g. standardized index (e.g. Lloyd-Hughes and Saunders, 2002; Shukla and Wood, 2008; Huang et al., 2014), cumulative precipitation anomaly (CPA), PDSI (Dai et al., 2004), regional deficiency index (RDI; Stahl, 2001; Hannaford et al., 2011), and fixed threshold level method to name a few (e.g. Hisdal et al., 2004; Lorenzo-Lacruz et al., 2013). Just as there is no single definition of drought, there is no single drought index that meets the requirements of all applications since various drought indicators are associated with specific drought types (Keyantash and Dracup, 2002; Hayes et al., 2007; Burke and Brown, 2008). For example, irrigation water use could lead to decreased stream flow and an increase of soil moisture in irrigated land concurrently (Leng et al., 2013, 2014a; Leng and Tang, 2014) leading to a period of hydrological drought but not of agricultural drought. However, even this picture may be incomplete as to truly understand agricultural drought dynamics one may need to consider crop types and water management practices in addition to the climatic conditions. Hence, it is clear that the SSWI (used here to assess agricultural droughts) is based on soil moisture anomalies only, and so may not be suitable to fully indicate the real agricultural drought. Despite these limitations however, it has been adopted for this purpose in a number of previous studies and so is used here in the same way (e.g. Vidal et al., 2010; Wang et al., 2011a, 2011b; Duan and Mei, 2014).

Finally, a high-resolution modeling approach through nesting high resolution RCMs within the GCMs could potentially be used to improve model performance (Gao et al., 2001, 2008; Yu et al., 2010) and could be adopted in hydrological climate impact assessments. Although this was not attempted here, it could be a part of future investigations. Similarly, it would be valuable to compare climate projections using both statistical and dynamical downscaling methods and examining the implications in hydrological climate change impact assessments in our future work since dynamically-downscaled climate data are increasing available over the China domain (Gao et al., 2011).

\section{Summary and conclusions}

Drought is a natural hazard that can have large impacts on various sectors of society, the environment and the economy. Within the context of future climate change, it is important for decision makers to comprehensively understand climate change impacts on all types of droughts (meteorological, agricultural, and hydrologic) at the regional scale and to map out and coordinate adaptation and mitigation strategies for these droughts. In this study, daily time series of soil moisture and runoff were examined on a 0.5 degree grid by driving the calibrated VIC model with downscaled/bias-corrected climate projections. On the time series of precipitation, and modeled soil moisture and runoff, the properties of droughts occurring in different parts of the hydrological cycle were comprehensively examined in a spatially consistent manner. The drought characteristics taken into account were the number of droughts, drought duration, and a standardized deficit volume (drought intensity) based on a standardized index for three types of droughts, meteorological, agricultural and hydrological. The major findings of this study can be summarized as follows.

For China as a whole, changes in drought severity, duration, and frequency suggest that meteorological, agricultural and hydrological droughts will become more severe, prolonged, and frequent in the near future. However, regional variations are large. Model results for
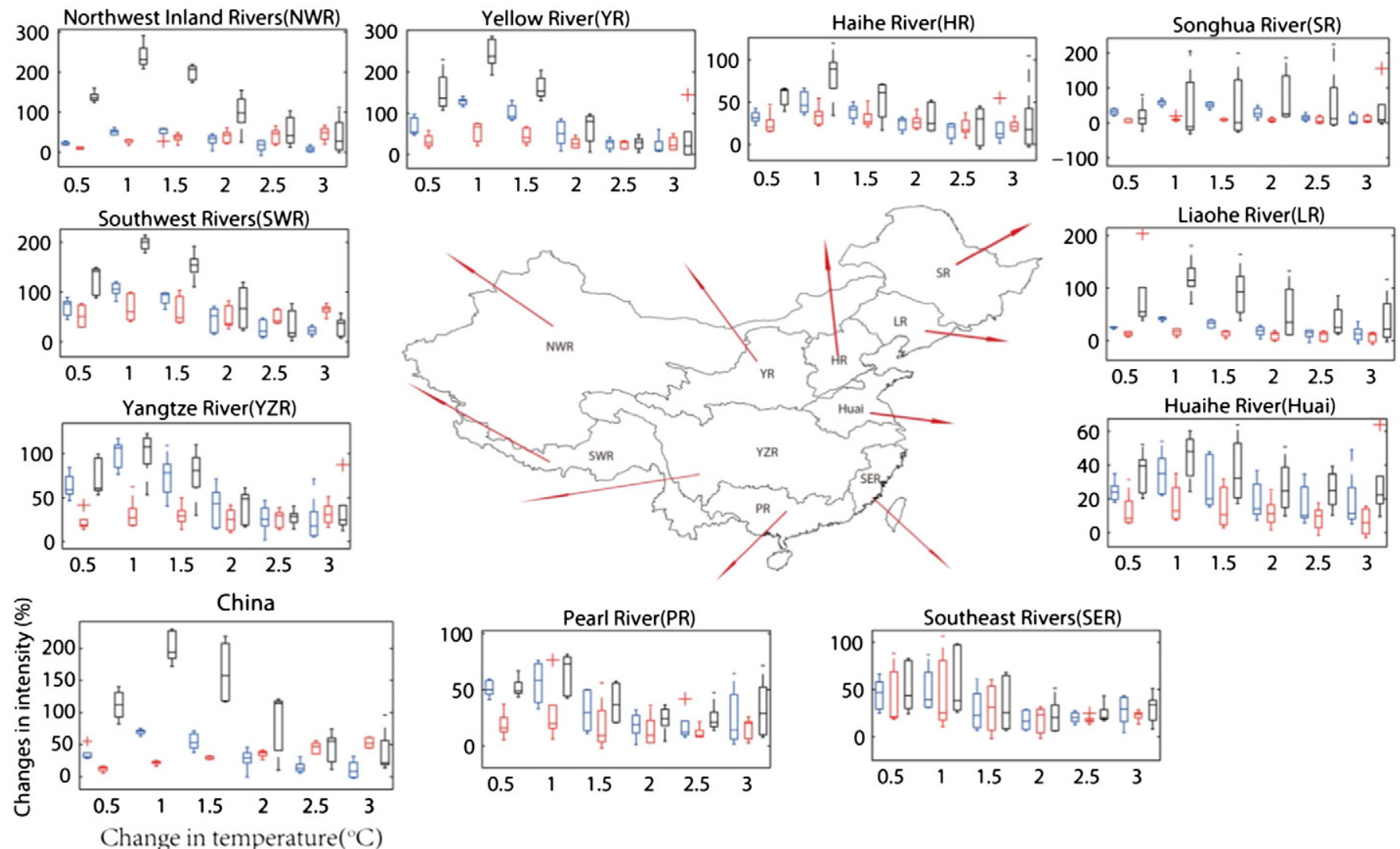

Change in temperature $\left({ }^{\circ} \mathrm{C}\right)$

SPI $\longrightarrow$ SSWI SRI

Fig. 8. Same as Fig. 6 but for drought intensity. 
areas of most of Xinjiang, the Tibetan Plateau, and large areas of Yunnan province show that the future droughts in these areas will become more intense, more frequent, and longer lasting in the near future. This will pose additional challenges to the agricultural productivity in these dry regions where water shortage is already severe and at a time when irrigation is expected to become more important to stabilize and increase food production for a growing population (Leng et al., in press). For parts of north central and northeastern China, a decrease in the frequency of meteorological and hydrological drought events and their durations are projected mainly due to a relatively large increase in precipitation amounts in these regions. Although uncertainties are high in the simulated results, we found that all five climate models projected the same direction of changes in drought properties (with

\section{Table 4}

Years when local temperature is larger than the period of $1971-2000$ by $0.5,1.0,1.5,2.5$ and $3{ }^{\circ} \mathrm{C}$. The years denote a period of 30 years of temperature averaging centered on that year.

\begin{tabular}{|c|c|c|c|c|c|c|c|}
\hline Region & Model & $\begin{array}{l}0.5 \\
{ }^{\circ} \mathrm{C}\end{array}$ & $1^{\circ} \mathrm{C}$ & $\begin{array}{l}1.5 \\
{ }^{\circ} \mathrm{C}\end{array}$ & $2{ }^{\circ} \mathrm{C}$ & $\begin{array}{l}2.5 \\
{ }^{\circ} \mathrm{C}\end{array}$ & $3{ }^{\circ} \mathrm{C}$ \\
\hline \multirow[t]{5}{*}{ China } & GFDL-ESM2M & 1998 & 2013 & 2030 & 2045 & 2057 & 2067 \\
\hline & HadGEM2-ES & 2000 & 2011 & 2022 & 2031 & 2040 & 2046 \\
\hline & IPSL-CM5A-LR & 1998 & 2012 & 2021 & 2030 & 2037 & 2044 \\
\hline & MIROC-ESM-CHEM & 2004 & 2012 & 2020 & 2026 & 2033 & 2038 \\
\hline & NorESM1-M & 2001 & 2017 & 2028 & 2037 & 2046 & 2054 \\
\hline \multirow{5}{*}{$\begin{array}{l}\text { Songhua River } \\
\text { (SR) }\end{array}$} & GFDL-ESM2M & 1999 & 2019 & 2032 & 2045 & 2056 & 2066 \\
\hline & HadGEM2-ES & 1999 & 2006 & 2019 & 2031 & 2040 & 2044 \\
\hline & IPSL-CM5A-LR & 1996 & 2011 & 2020 & 2028 & 2035 & 2044 \\
\hline & MIROC-ESM-CHEM & 2001 & 2012 & 2017 & 2023 & 2030 & 2033 \\
\hline & NorESM1-M & 1997 & 2010 & 2020 & 2030 & 2037 & 2045 \\
\hline \multirow[t]{5}{*}{ Liaohe River (LR) } & GFDL-ESM2M & 1998 & 2018 & 2034 & 2045 & 2057 & 2070 \\
\hline & HadGEM2-ES & 2003 & 2014 & 2023 & 2037 & 2043 & 2048 \\
\hline & IPSL-CM5A-LR & 1997 & 2012 & 2021 & 2030 & 2036 & 2044 \\
\hline & MIROC-ESM-CHEM & 2002 & 2012 & 2019 & 2026 & 2032 & 2035 \\
\hline & NorESM1-M & 1998 & 2014 & 2024 & 2033 & 2041 & 2049 \\
\hline \multirow{5}{*}{$\begin{array}{l}\text { Northwest Inland } \\
\text { Rivers (NWR) }\end{array}$} & GFDL-ESM2M & 1997 & 2010 & 2026 & 2041 & 2053 & 2063 \\
\hline & HadGEM2-ES & 1997 & 2007 & 2018 & 2028 & 2036 & 2043 \\
\hline & IPSL-CM5A-LR & 1997 & 2008 & 2019 & 2028 & 2033 & 2041 \\
\hline & MIROC-ESM-CHEM & 1999 & 2009 & 2017 & 2023 & 2030 & 2035 \\
\hline & NorESM1-M & 1998 & 2013 & 2025 & 2034 & 2042 & 2052 \\
\hline \multirow[t]{5}{*}{ Haihe River (HR) } & GFDL-ESM2M & 1997 & 2019 & 2036 & 2047 & 2061 & 2077 \\
\hline & HadGEM2-ES & 2004 & 2017 & 2026 & 2035 & 2042 & 2048 \\
\hline & IPSL-CM5A-LR & 1998 & 2013 & 2022 & 2031 & 2039 & 2047 \\
\hline & MIROC-ESM-CHEM & 2007 & 2015 & 2023 & 2030 & 2034 & 2041 \\
\hline & NorESM1-M & 2002 & 2017 & 2028 & 2037 & 2048 & 2057 \\
\hline \multirow[t]{5}{*}{ Yellow River (YR) } & GFDL-ESM2M & 1997 & 2011 & 2029 & 2045 & 2058 & 2070 \\
\hline & HadGEM2-ES & 1998 & 2010 & 2022 & 2031 & 2042 & 2048 \\
\hline & IPSL-CM5A-LR & 1999 & 2012 & 2021 & 2030 & 2038 & 2045 \\
\hline & MIROC-ESM-CHEM & 2007 & 2016 & 2024 & 2032 & 2037 & 2043 \\
\hline & NorESM1-M & 2002 & 2017 & 2028 & 2038 & 2048 & 2057 \\
\hline \multirow{5}{*}{$\begin{array}{l}\text { Yangtze River } \\
\text { (YZR) }\end{array}$} & GFDL-ESM2M & 2001 & 2015 & 2029 & 2047 & 2063 & 2072 \\
\hline & HadGEM2-ES & 2003 & 2017 & 2026 & 2035 & 2043 & 2049 \\
\hline & IPSL-CM5A-LR & 2001 & 2016 & 2025 & 2033 & 2040 & 2047 \\
\hline & MIROC-ESM-CHEM & 2007 & 2016 & 2022 & 2029 & 2036 & 2043 \\
\hline & NorESM1-M & 2008 & 2023 & 2033 & 2042 & 2051 & 2060 \\
\hline \multirow{5}{*}{$\begin{array}{l}\text { Huaihe River } \\
\text { (Huai) }\end{array}$} & GFDL-ESM2M & 1998 & 2016 & 2033 & 2047 & 2065 & 2077 \\
\hline & HadGEM2-ES & 2003 & 2018 & 2028 & 2038 & 2044 & 2050 \\
\hline & IPSL-CM5A-LR & 2000 & 2016 & 2025 & 2032 & 2041 & 2049 \\
\hline & MIROC-ESM-CHEM & 2007 & 2015 & 2023 & 2030 & 2036 & 2043 \\
\hline & NorESM1-M & 2006 & 2023 & 2034 & 2044 & 2052 & 2060 \\
\hline \multirow{5}{*}{$\begin{array}{l}\text { Southeast Rivers } \\
\text { (SER) }\end{array}$} & GFDL-ESM2M & 2003 & 2020 & 2040 & 2059 & 2072 & 2083 \\
\hline & HadGEM2-ES & 2002 & 2016 & 2026 & 2038 & 2046 & 2054 \\
\hline & IPSL-CM5A-LR & 2006 & 2021 & 2031 & 2040 & 2050 & 2057 \\
\hline & MIROC-ESM-CHEM & 2007 & 2016 & 2025 & 2033 & 2041 & 2052 \\
\hline & NorESM1-M & 2013 & 2028 & 2038 & 2049 & 2061 & 2072 \\
\hline \multirow{5}{*}{$\begin{array}{l}\text { Southwest Rivers } \\
\text { (SWR) }\end{array}$} & GFDL-ESM2M & 2000 & 2013 & 2027 & 2043 & 2055 & 2065 \\
\hline & HadGEM2-ES & 2004 & 2017 & 2027 & 2037 & 2045 & 2052 \\
\hline & IPSL-CM5A-LR & 1999 & 2010 & 2020 & 2029 & 2035 & 2041 \\
\hline & MIROC-ESM-CHEM & 2006 & 2014 & 2021 & 2028 & 2034 & 2041 \\
\hline & NorESM1-M & 2006 & 2021 & 2032 & 2042 & 2051 & 2060 \\
\hline \multirow[t]{5}{*}{ Pearl River (PR) } & GFDL-ESM2M & 2003 & 2023 & 2044 & 2058 & 2071 & 2083 \\
\hline & HadGEM2-ES & 2006 & 2019 & 2028 & 2037 & 2044 & 2052 \\
\hline & IPSL-CM5A-LR & 2007 & 2021 & 2032 & 2040 & 2050 & 2057 \\
\hline & MIROC-ESM-CHEM & 2013 & 2020 & 2027 & 2034 & 2042 & 2051 \\
\hline & NorESM1-M & 2014 & 2029 & 2039 & 2050 & 2060 & 2071 \\
\hline
\end{tabular}

only the magnitudes of changes being different), suggesting a relatively high confidence in the projections.

The propagation of meteorological droughts to agricultural and hydrological droughts in a warming climate is complex and non-linear. Hence, the response of droughts in different domains of the hydrological cycle to climate warming could be different. For example, the most prolonged agricultural droughts increased in duration from 6 to 26 months as projected by HadGEM2-ES and MIROC-ESM-CHEM, whereas the most prolonged meteorological and hydrological droughts changed little in duration as projected by the same models. Another example of this complex and unique response to climate warming is that the impact of climate change on the intensity of the most severe hydrological droughts is more dramatic than changes in the intensity of either meteorological or agricultural droughts. This can be seen in that the most severe hydrological drought intensity is about 3 times the baseline, whereas the most severe meteorological and agricultural drought intensities are only about 2 times and 1.5 times the baseline respectively. In addition, the frequency of long-term agricultural droughts will increase more than that of short-term droughts, while the opposite is true for meteorological and hydrological droughts while in terms of the percentage of people and land area affected in China, the increase in extreme meteorological droughts could generally be more harmful than agricultural and hydrological droughts. Hence, each drought type responds to increasing temperature in a unique way with different drought properties either more or less affected by climate change when compared to the other drought types.

This complex drought response is further evident in the unique ways in which each drought type and region of China responds to continued increases in temperature (from $1{ }^{\circ} \mathrm{C}$ to $3{ }^{\circ} \mathrm{C}$ ). Agricultural drought frequency, intensity and duration are predicted to increase for all local temperature increments up to $3{ }^{\circ} \mathrm{C}$ for the whole country as well as all ten river basins in China. However, no or only small changes in meteorological and hydrological drought frequency are predicted for almost all temperature increments across the whole of China and in each region. In contrast, the largest increases of meteorological and hydrological drought duration and intensity are found when temperature increases by $1{ }^{\circ} \mathrm{C}$ for most river basins (and both duration and intensity may actually decrease with further warming for these two drought types). This suggests that different adaption/mitigation strategies should be adopted to cope with future climate change associated with specific warming amounts.

Through driving the calibrated VIC model with five bias-corrected climate projections in RCP8.5 scenario, our results show a robust increase of droughts in the future in terms of frequency, duration and intensity when averaged for the whole country but with large regional variations. More extreme droughts than mean droughts are projected under climate warming, with huge potential social impacts. Importantly, meteorological, agricultural and hydrological droughts are found to respond differently to the same climate warming amounts. Our results highlight that specific adaptation and mitigation strategies for specific sectors should be taken to cope with future climate change associated with specific warming magnitudes. Although to fully include and address the uncertainties from all sources is challenging and not within the scope of this study since there is no efficient way to handle all of them, it is important to keep in mind the uncertainties of this study, which is inevitable in climate change impact studies. And our results may depend on the emission scenario, GCMs, impact model, time periods and drought indicators selected for analysis.

\section{Acknowledgments}

We thank the Editor and reviewers for their careful reviews and constructive comments/suggestions which led to substantial improvements in the manuscript. This work was supported by the National Natural Science Foundation of China (grant no. 41171031), the National Basic Research Program of China (grant no. 2012CB955403), and the 
Hundred Talents Program of the Chinese Academy of Sciences. This work has been conducted under the framework of ISI-MIP. The ISIMIP Fast Track project was funded by the German Federal Ministry of Education and Research (BMBF) with project funding reference number 01LS1201A. Responsibility for the content of this publication lies with the author.

\section{References}

Aich, V., Liersch, S., Vetter, T., Huang, S., Tecklenburg, J., Hoffmann, P., Koch, H., Fournet, S. Krysanova, V., Müller, E.N., Hattermann, F.F., 2014. Comparing impacts of climate change on streamflow in four large African river basins. Hydrol. Earth Syst. Sci. 18 1305-1321.

Andreadis, K.M., Clark, E.A., Wood, A.W., Hamlet, A., Lettenmaier, D., 2005. 20th century drought in the conterminous United States. J. Hydrometeorol. 6, 885-1001.

Batjes, N.H., 1995. A Homogenized Soil Data File for Global Environmental Research: A Subset of FAO, ISRIC and NRCS Profiles International Soil Reference and Information Center (ISRIC), Wageningen, The Netherlands.

Biasutti, M., Sobel, A.H., Camargo, S.J., Creyts, T.T., 2012. Projected changes in the physical climate of the Gulf Coast and Caribbean. Clim. Chang. 112, 819-845.

Burke, E.J., 2011. Understanding the sensitivity of different drought metrics to the drivers of drought 20 under increased atmospheric $\mathrm{CO}_{2}$. J. Hydrometeorol. 12, 1318-1393.

Burke, E.J., Brown, S.J., 2008. Evaluating uncertainties in the projection of future drought J. Hydrometeorol. 9, 292-299.

Chen, J., Brissette, F.P., Leconte, R., 2011. Uncertainty of downscaling method in quantifying the impact of climate change on hydrology. J. Hydrol. 401, 190-202.

Cosby, B.J., Hornberger, G.M., Clapp, R.B., Ginn, T.R., 1984. A statistical exploration of the relationships of soil moisture characteristics to the physical properties of soils. Water Resour. Res. 20, 682-690.

Dai, A., 2012. Increasing drought under global warming in observations and models. Nat. Clim. Chang. 3, 52-58.

Dai, A., Trenberth, K.E., Qian, T.T., 2004. A global data set of Palmer Drought Severity Index for 1870-2002: relationship with soil moisture and effects of surface warming. J. Hydrometeorol. 5, 1117-1130.

Dankers, R., et al., 2014. First look at changes in flood hazard in the Inter-Sectoral Impact Model Intercomparison Project ensemble. Proc. Natl. Acad. Sci. U. S. A. 111 (9), 3257-3261.

Diffenbaugh, N.S., Scherer, M., Ashfaq, M., 2013. Response of snow-dependent hydrologic extremes to continued global warming. Nat. Clim. Chang. http://dx.doi.org/10.1038/ NCLIMATE1732.

Döll, P., Fiedler, K., Zhang, J., 2009. Global-scale analysis of river flow alterations due to water withdrawals and reservoirs. Hydrol. Earth Syst. Sci. 13, 2413-2432.

Duan, K., Mei, Y., 2014. Comparison of meteorological, hydrological and agricultura drought responses to climate change and uncertainty assessment. Water Resour. Manag. 28, 5039-5054.

Dubrovsky, M., et al., 2009. Application of relative drought indices in assessing climatechange impacts on drought conditions in Czechia. Theor. Appl. Climatol. 96, 155-171.

Elliot, J., et al., 2014. Constraints and potentials of future irrigation water availability on agricultural production under climate change. Proc. Natl. Acad. Sci. U. S. A. 111 (9), 3239-3244.

FAO, 1998. Digital soil map of the world and derived soil properties. Land and 410 Water Digital Media Series 1, Food and Agriculture Organization, CD-ROM

Gao, X.J., Zhao, Z.C., Ding, Y.H., et al., 2001. Climate change due to greenhouse effects in China as simulated by a regional climate model. Adv. Atmos. Sci. 18, 1224-1230.

Gao, X., Zhao, Z., Giorgi, F., 2002. Changes of extreme events in regional climate simulations over East Asia. Adv. Atmos. Sci. 19, 927-942.

Gao, X., Shi, Y., Song, R., Giorgi, F., Wang, Y., Zhang, D., 2008. Reduction of future monsoon precipitation over China: comparison between a high resolution RCM simulation and the driving GCM. Meteorog. Atmos. Phys. 100, 73-86.

Gao, X., Shi, Y., Giorgi, F., 2011. A high resolution simulation of climate change over China. Sci. China Earth Sci. 54, 462-472.

Guo, S., Wang, J., Xiong, L., et al., 2002. A macro-scale and semi-distributed monthly water balance model to predict climate change impacts in China. J. Hydrol. 268, 1-15.

Haddeland, I., et al., 2014. Global water resources affected by human interventions and climate change. Proc. Natl. Acad. Sci. U. S. A. 111 (9), 3251-3256.

Hagemann, S., Chen, C., Haerter, J.O., Heinke, J., Gerten, Piani, C., 2011. Impact of a statistical bias correction on the projected hydrological changes obtained from three GCMs and two hydrology models. J. Hydrometeorol. 12, 556-578.

Hagemann, S., et al., 2013. Climate change impact on available water resources obtaine using multiple global climate and hydrology models. Earth Syst. Dyn. 4, 129-144.

Hinkel, J., et al., 2014. Coastal flood damage and adaptation costs under 21st century sealevel rise. Proc. Natl. Acad. Sci. http://dx.doi.org/10.1073/pnas.1222469111.

Hannaford, J., Lloyd-Hughes, B., Keef, C., Parry, S., Prudhomme, C., 2011. Examining the arge-scale spatial coherence of European drought using regional indicators of precipitation and streamflow deficit. Hydrol. Process. 25, 1146-1162.

Hansen, M.C., DeFries, R.S., Townshend, J.R.G., Sohlberg, R., 2000. Global land cover classification at $1 \mathrm{~km}$ spatial resolution using a classification tree approach. Int. J. Remote Sens. 21, 1331-1364.

Hisdal, H., Tallaksen, L.M., Clausen, B., Peters, E., Gustard, A., 2004. Hydrological Drought Characteristics. Developments in Water Science, 48, 2004, Chapter 5. Elsevier Science B.V, Amsterdam, the Netherlands, pp. 139-198.

Hayes, M.J., Alvord, C., Lowrey, J., 2007. Drought indices. Intermountain West Clim. Summ. 3 (6), 2-6.
Hayhoe, et al., 2004. Emissions pathways, climate change, and impacts on California. Proc. Natl. Acad. Sci. U. S. A. 101 (34), 12422-12427.

Hempel, S., Frieler, K., Warszawski, L., Schewe, J., Piontek, F., 2013. A trend-preserving bias correction - the ISI-MIP approach. Earth Syst. Dyn. 4, 219-236.

Hisdal, H., Stahl, K., Tallaksen, L.M., Demuth, S., 2001. Have streamflow droughts in Europe more severe of frequent? Int. J. Climatol. 21, 317-333.

Huang, S., Chang, J., Huang, Q., Chen, Y., 2014. Spatio-temporal changes and frequency analysis of drought in the Wei River Basin, China. Water Resour. Manag. 28, 3095-3110.

IPCC, 2013. Summary for policymakers. Climate change 2013. The science of climate change. Contribution of Working Group I to the Fifth Assessment Report of the Intergovernmental Panel on Climate Change.

Jiang, D.B., Tian, Z.P., 2013. East Asian monsoon change for the 21st century: results of CMIP3 and CMIP5 models. Chin. Sci. Bull. 58, 1427-1435.

Jiang, T., Chen, Y., Xu, C., et al., 2007. Comparison of hydrological impacts of climate change simulated by six hydrological models in the Dongjiang Basin, South China. J. Hydrol. 336, 316-333.

Keyantash, J., Dracup, J.A., 2002. The quantification of drought: an evaluation of the drought indices. Bull. Am. Meteorol. Soc. 83, 1167-1180.

Kirono, D.G.C., Kent, D.M., Hennessy, K.J., Mpelasoka, F., 2011. Characteristics of Australian droughts under enhanced greenhouse conditions: results from 14 global climate models. J. Arid Environ. 75, 566-575.

Leng, G., Tang, Q., 2014. Modeling the impacts of future climate change on irrigation over China: sensitivity to adjusted projections. J. Hydrometeorol. 15, 2085-2103.

Leng, G., Huang, M., Tang, Q., Sacks, W.J., Lei, H., Leung, L.R., 2013. Modeling the effects of irrigation on land surface fluxes and states over the conterminous United States: sensitivity to input data and model parameters. J. Geophys. Res. 118 (17), 9789-9803.

Leng, G., Huang, M., Tang, O., Gao, H., Leung, L.R., 2014a. Modeling the effects of groundwater-fed irrigation on terrestrial hydrology over the conterminous United States. J. Hydrometeorol. 15, 957-972.

Leng, G., Tang, Q., Huang, M., Hong, Y., Leung, L.R., 2015. Projected changes in mean and interannual variability of surface water over continental China. Sci. China Earth Sci. http://dx.doi.org/10.1007/s11430-014-4987-0 (in press)

Li, Y.H., Xu, H.M., Liu, D., 2009. Features of the extremely severe drought in the east of Southwest China and anomalies of atmospheric circulation in summer 2006. Acta Meteorol. Sin. 25, 122-132.

Li, Z., Liu, W.Z., Zhang, X.C., et al., 2010. Assessing and regulating the impacts of climate change on water resources in the Heihe watershed on the Loess Plateau of China. Sci. China Earth Sci. 53, 710-720.

Liang, X., Lettenmaier, D.P., Wood, E.F., Burges, S.J., 1994. A simple hydrologically based model of land surface water and energy fluxes for GSMs. J. Geophys. Res. 99 (D7), $14415-14428$.

Liang, X., Lettenmaier, D.P., Wood, E.F., 1996. One-dimensional statistical dynamic recurrentation of subgrid spatial variability of precipitation in the two-layer Variable Infiltration Capacity model. J. Geophys. Res. 101 (D16), 21403-21422

Lloyd-Hughes, B., Saunders, M.A., 2002. A drought climatology for Europe. Int. J. Climatol. $22,1571-1592$

Lopez, Ana, Suckling, Emma B., Smith, Leonard A., 2014. Robustness of pattern scaled climate change scenarios. Clim. Chang. 122, 555-566.

Lorenzo-Lacruz, J., Mor'an-Tejeda, E., Vicente-Serrano, S.M., L'opez-Moreno, J.I., 2013. Streamflow droughts in the Iberian Peninsula between 1945 and 2005: spatial and temporal patterns. Hydrol. Earth Syst. Sci. 17, 119-134.

Loukas, A., Vasiliades, L., 2004. Probabilistic analysis of drought spatiotemporal characteristics in Thessaly region, Greece. Nat. Hazards Earth Syst. Sci. 4, 719-731.

Loukas, A., Vasiliades, L., Tzabiras, J., 2007. Evaluation of climate change on drought impulses in Thessaly, Greece. Eur. Water J. 17/18.

Loukas, A., Vasiliades, L., Tzabiras, J., 2008. Climate change effects on drought severity. Adv. Geosci. 17, 23-29.

$\mathrm{Ma}, \mathrm{Z}$., Fu, C., 2003. Interannual characteristics of the surface hydrological variables over the arid and semi-arid areas of northern China. Global Planet. Chang. 37 $189-200$.

Mariotti, A., Zeng, N., Yoon, J., Artale, V., Navarra, A., Alpert, P., Li, L.Z.X., 2008. Mediterranean water cycle changes: transition to drier 21st century conditions in observations and CMIP3 simulations. Environ. Res. Lett. 3, 044001

Maurer, E.P., 2007. Uncertainty in hydrologic impacts of climate change in the Sierra Nevada, California under two emissions scenarios. Clim. Chang. 82, 309-325.

McKee, T.B., Doesken, N.J., Kliest, J., 1993. The relationship of drought frequency and duration to time scales. Paper Presented at the 8th Conference of Applied Climatology, Am. Meterol. Soc., Anaheim, Calif.

Mishra, A.K., Desai, V.R., 2005. Spatial and Temporal Drought Analysis in the Kansabati River Basin, India. Int. J. River Basin Manag. IAHR 3 (1), 31-41.

Mishra, A.K., Singh, V.P., 2010. A review of drought concepts. J. Hydrol. 391, 202-216.

Moss, R.H., et al., 2010. The next generation of scenarios for climate change research and assessment Nature 463, 747-756.

MWRC, 2011. China Water Resources Bulletin 2011. China WaterPower Press, Beijing.

Orlowsky, B., Hoekstra, A.Y., Gudmundsson, L., Seneviratne, S.I., 2014. Today's virtual water consumption and trade under future water scarcity. Environ. Res. Lett. 9, 074007.

Piani, C., et al., 2010. Statistical bias correction of global simulated daily precipitation and temperature for the application of hydrological models. J. Hydrol. 395, 199-215.

Piontek, F., et al., 2014. Multisectoral climate impact hotspots in a warming world. Proc. Natl. Acad. Sci. U. S. A. 111, 3233-3238

Portmann, F.T., et al., 2013. Impact of climate change on renewable groundwater resources: assessing the benefits of avoided greenhouse gas emissions using selected CMIP5 climate projections. Environ. Res. Lett. 8, 024023. 
Prudhomme, C., et al., 2014. Hydrological droughts in the 21st century: hotspots and uncertainties from a global multi-model ensemble experiment. Proc. Natl. Acad. Sci. U. S. A. 111 (9), 3262-3267.

Qiu, J., 2010. China drought highlights future climate threats. Nature 465, 142-143.

Rogelj, J., Meinshausen, M., Knutti, R., 2012. Global warming under old and new scenarios using IPCC climate sensitivity range estimates. Nat. Clim. Chang. 2, 248-253.

Stahl, K., 2001. Hydrological Drought - a Study across Europe. (Ph.D. thesis). AlbertLudwigs-Universität, Freiburg, Germany.

Schewe, J., Heinke, J., Gerten, D., et al., 2014. Multimodel assessment of water scarcity under climate change. Proc. Natl. Acad. Sci. U. S. A. 111, 3249-3250.

Sheffield, J., Wood, E.F., 2008. Projected changes in drought occurrence under future global warming from multi-model, multi-scenario, IPCC AR4 simulations. Clim. Dyn. 31, 79-105.

Shukla, S., Wood, A.W., 2008. Use of a standardized runoff index for characterizing hydrologic drought. Geophys. Res. Lett. 35, L02405.

Tallaksen, L.M., Lanen, H.A., van., J., 2004. Hydrological drought - processes and estimation methods for streamflow and groundwater. Developments in Water Sciences 48. Elsevier B.V., The Netherlands (580 pp.).

Tang, Q., Lettenmaier, D.P., 2012. 21st century runoff sensitivities of major global river basins. Geophys. Res. Lett. 39, L06403.

Trenberth, K.E., et al., 2014. Global warming and changes in drought. Nat. Clim. Chang. 4 , $17-22$.

Van Loon, A.F., Van Lanen, H.A.J., 2012. A process-based typology of hydrological drought. Hydrol. Earth Syst. Sci. 16, 1915-1946. http://dx.doi.org/10.5194/hess-16-1915-2012.

Vicuna, S., Maurer, E.P., Joyce, B., Dracup, J.A., Purkey, D., 2007. The sensitivity of California water resources to climate change scenarios. JAWRA 43, 482-498.

Vidal, J.P., Martin, E., Franchistéguy, L., Habets, F., Soubeyroux, J.M., Blanchard, M., Baillon, M., 2010. Multilevel and multiscale drought reanalysis over France with the SafranIsba-Modcou hydrometeorological suite. Hydrol. Earth Syst. Sci. 14, 459-478.

Wang, Z., Zhai, P., 2003. Climate change in drought over northern China during 19502000. Acta Geogr. Sin. 58, 61-68.

Wang, A., Lettenmaier, D.P., Sheffield, J., 2011a. Soil moisture drought in China, 19502006. J. Clim. 24, 3257-3271.

Wang, D., Hejazi, M., Cai, X., Valocchi, A.J., 2011b. Climate change impact on meteorological, hydrological, and agricultural drought in central Illinois. Water Resour. Res. 47, W09527.

Wang, G.Q., Zhang, J.Y., Jin, J.L., et al., 2012. Assessing water resources in China using PRECIS projections and a VIC model. Hydrol. Earth Syst. Sci. 16, 231-240.

Wang, L., Chen, W., Zhou, W., 2014. Assessment of future drought in Southwest China based on CMIP5 multimodel projections. Adv. Atmos. Sci. 31, 1035-1050.

Warszawski, L., et al., 2013. The Inter-Sectoral Impact Model Intercomparison Project (ISI-MIP): project framework. Proc. Natl. Acad. Sci. U. S. A. http://dx.doi.org/10. 1073/pnas.1312330110 (early online edition).

Weedon, G.P., et al., 2011. Creation of the WATCH Forcing Data and Its Use to Assess Global and Regional Reference Crop Evaporation over Land during the Twentieth Century. J. Hydrometeorol. 12, 823-848.

Wilhite, D.A., 2000. Drought as a natural hazard: concepts and definitions. In: Wilhite, D.A. (Ed.), Drought: A Global Assessment vol. 1. Routledge, New York, pp. 1-18.

Wilhite, D.A., Glantz, M.H., 1985. Understanding the drought phenomenon: the role of definitions. Water Int. 10, 111-120.
Wilhite, D.A., Hayes, M.J., Knutson, C., Smith, K.H., 2000. Planning for drought: moving from crisis to risk management. J. Am. Water Resour. Assoc. 36, 697-710.

Wilks, D.S., Eggleston, K.L., 1992. Estimating Monthly and Seasonal Precipitation Distributions Using the 30- and 90-Day Outlooks. J. Clim. 5, 252-259.

Wisser, D., Fekete, B.M., Vörösmarty, C.J., Schumann, A.H., 2010. Reconstructing 20th century global hydrography: a contribution to the Global Terrestrial Network- Hydrology (GTN-H). Hydrol. Earth Syst. Sci. 14, 1-24.

Wu, Z., Lu, G., Wen, L., Lin, C., 2011. Reconstructing and analyzing China's fifty-nine year (1951-2009) drought history using hydrological model simulation. Hydrol. Earth Syst. Sci. 15, 2881-2894.

Wu, J., Gao, X., 2013. A gridded daily observation dataset over China region and comparison with the other datasets. Chin. J. Geophys. 56 (4), 1102-1111.

$\mathrm{Xu}, \mathrm{Y} ., \mathrm{Xu}, \mathrm{C} . \mathrm{H} ., 2$ 2012a. Preliminary assessment of simulations of climate changes over China by CMIP5 multi-models. Atmos. Oceanic Sci. Lett. 5, 489-494.

$\mathrm{Xu}$, C.H., Xu, Y., 2012b. The projection of temperature and precipitation over China under RCP scenarios using a CMIP5 multi-model ensemble. Atmos. Oceanic Sci. Lett. 5, 527-533.

Xu, Y., Gao, X., Shen, Y., Xu, C.H., Shi, Y., Giorgi, F., 2009a. A daily temperature dataset over China and its application in validating a RCM simulation. Adv. Atmos. Sci. 26 (4), 763-772.

Xu, Y., Xu, C., Gao, X., Luo, Y., 2009b. Projected changes in temperature and precipitation extremes over the Yangtze River Basin of China in the 21st century. Quatern. Int. 208, 44-52.

Xu, Z., Zhao, F., Li, J., 2009c. Response of runoff to climate change in the headwater catchment of the Yellow River basin. Quatern. Int. 208, 62-75.

Xu, J., Shi, Y., Gao, X., 2012. Changes in extreme events as simulated by a high-resolution regional climate model for the next 20-30 years over China. Atmos. Oceanic Sci. Lett. 5, 483-488.

Xu, J., Shi, Y., Gao, X., et al., 2013. Projected changes in climate extremes over China in the 21 st century from a high resolution regional climate model (RegCM3). Chin. Sci. Bull. $58,1443-1452$.

Yang, J., Gong, D., Wang, W., Hu, M., Mao, R., 2012. Extreme drought event of 2009/2010 over southwestern China. Meteorol. Atmos. Phys. 115, 173-184.

Yu, E., Wang, H.J., Sun, J.Q., 2010. A quick report on a dynamical downscaling simulation over china using the nested model. Atmos. Oceanic Sci. Lett. 3, 325-329.

Zhai, J., Su, B., Krysa nova, V., 2010. Spatial variation and trends in PDSI and SPI indices and their relation to streamflow in 10 large regions of China. J. Clim. 23, 649-663. http:// dx.doi.org/10.1175/2009JCLI2968.1.

Zhang, J., Jiang, L., Feng, Z., Li, P., 2012a. Detecting effects of the recent drought on vegetation in southwestern China. J. Resour. Ecol. 3, 43-49.

Zhang, L., Xiao, J.F., Li, J., Wang, K., Lei, L.P., Guo, H.D., 2012b. The 2010 spring drought reduced primary productivity in southwestern China. Environ. Res. Lett. 7, 045706.

Zhang, X., Tang, Q., Pan, M., Tang, Y., 2014. A long-term land surface hydrologic fluxes and states dataset for China. J. Hydrometeorol. 15, 2067-2084.

Zou, X., Zhai, P., Zhang, Q., 2005. Variations in droughts over China: 1951-2003. Geophys. Res. Lett. 32, L04707. 